\title{
Assessing Urban Forest Canopy Cover in Great Plain Conservation Area (Düzce city, Turkey) between 1984 and 2015
}

\author{
Zennure UÇAR $^{1 *}$, Remzi EKER ${ }^{1}$, Abdurrahim AYDIN²
}

\author{
${ }^{1}$ İzmir Katip Çelebi University, Faculty of Forestry, Department of Forest Engineering, 35620 İzmir, Turkey - zennure.ucar@ikc.edu.tr \\ ${ }^{1}$ İzmir Katip Çelebi University, Faculty of Forestry, Department of Forest Engineering, 35620, İzmir, Turkey - remzi.eker@ikc.edu.tr \\ ${ }^{2}$ Düzce University, Faculty of Forestry, Department of Forest Engineering, 81620, Düzce, Turkey - aaydin@ duzce.edu.tr
}

KEYWORDS: Urban forestry, Aerial photography, GIS, Tree canopy cover, Sampling

\begin{abstract}
:
Urban trees and forests are essential components of the urban environment. They can provide numerous ecosystem services and goods, including but not limited to recreational opportunities and aesthetic values, removal of air pollutants, improving air and water quality, providing shade and cooling effect, reducing energy use, and storage of atmospheric $\mathrm{CO}_{2}$. However, urban trees and forests have been in danger of being lost by dense housing resulting from population growth in the cities since the 1950s, leading to increased local temperature, pollution level, and flooding risk. Thus, determining the status of urban trees and forests is necessary for comprehensive understanding and quantifying the ecosystem services and goods. Tree canopy cover is a relatively quick, easy to obtain, and cost-effective urban forestry metric broadly used to estimate ecosystem services and goods of the urban forest. This study aimed to determine urban forest canopy cover areas and monitor the changes between 1984-2015 for the Great Plain Conservation area (GPCA) that has been declared as a conservation Area (GPCA) in 2017, located on the border of Düzce City (Western Black Sea Region of Turkey). Although GPCA is a conservation area for agricultural purposes, it consists of the city center with 250,000 population and most settlement areas. A random point sampling approach, the most common sampling approach, was applied to estimate urban tree canopy cover and their changes over time from historical aerial imageries. Tree canopy cover ranged from $16.0 \%$ to $27.4 \%$ within the study period. The changes in urban canopy cover between 1984-1999 and 1999-2015 were statistically significant, while there was no statistical difference compared to the changes in tree canopy cover between 1984-2015. The result of the study suggested that an accurate estimate of urban tree canopy cover and monitoring long-term canopy cover changes are essential to determine the current situation and the trends for the future. It will help city planners and policymakers in decisionmaking processes for the future of urban areas.
\end{abstract}

\section{INTRODUCTION}

Population growth in urban areas has been increased rapidly. According to the UN (2018), 55\% of the world's population lives in cities, while the rest live in rural areas. In the 1950s, this rate was $30 \%$ and $70 \%$ for urban and rural areas, respectively. It is also projected that by $2050,68 \%$ of the world population will be living in the cities. A similar trend has been observed in Turkey. In $2017,74 \%$ of the population in Turkey lived in the cities, which is relatively higher than the world average (World bank 2017). The growth of the population had a significant direct or indirect impact on land cover change processes. In particular, the need for infrastructure such as housing, transportation, educational, and health care facilities destroys trees, forests, and green areas in, adjacent, or around the cities. Thus, it results in degradation of the structure, pattern, and function of the urban ecosystem in and around urban areas (Nowak 1993, McPherson et al., 2011, Berland 2012, Sağlam and Elvan, 2017).

Urban forest generally refers to all woody vegetation, including street trees on public and private lands, urban parks, and other trees located on residential properties, commercial land, and other lands within a city (Nowak et al., 2010, Berland 2012, Richardson and Moskal 2014). The urban forest is a significant component of the urban environment. It provides many benefits to the human being, including recreational opportunities and aesthetic values that improve human health and well-being and increase the value of neighborhoods. They also improve air and water quality and biodiversity and reduce energy use and greenhouse gas effect by facilitating the cooling effect. (Dwyer et al., 1992, Akbari 2002, Konijnendijk and Randrup 2004, Nowak et al., 2006, Nowak et al., 2010, Berland 2012, Richardson and Moskal 2014, Pasher et al., 2014, Safford et al., 2013, Parmehr et al., 2016, Kaspar et al., 2017).

Urban forestry has been defined as the artistic, technological, and scientific management of trees and tree communities in or around the city (Jorgensen,1974, Miller 1997, Konijnendijk et al., 2006). The concept of urban forestry may vary depending on the forestry practices countries apply and the presence of their forests. However, the most significant difference in urban forestry between countries arises from the areas considered as urban forests. In some countries (i.e., U.S.A., Canada, China, and most countries in Europe), regardless of the ownership, a single tree within a settlement area, trees on the roadsides, a single tree or small groups of trees in park and gardens are considered as an urban forest (Raundrup et al., 2005, Konijnendijk et al., 2006, Sağlam and Özkan 2011, FAO 2017). In other countries (such as Turkey), only state forests in or around the city, which provide aesthetic, psychological, economic, supportive, and sociological benefits to the society, are counted as urban forests. Still, a single tree in settlement areas is not considered as an urban forest (MYY 2006, Yeşil et al., 2010, Sağlam and Özkan 2011, Sağlam and Elvan 2017). 
Ecosystem services provided by urban forests in the city are directly related to the area covered by tree canopy, the ratio of the area covered by the crown of the tree (leaves, branches, and trunk) when viewed from above, and generally estimated as a percentage. It is a simple, well-known, and most often used metric to measure urban forest coverage (Nowak and Greenfield 2012, Berland 2012, Richardson and Moskal 2014, Grove et al., 2006, Doick et al., 2020). Some cities integrated this metric into management plans and policies, such as the city of Los Angeles, CA, USA. First, tree canopy cover was assessed for Los Angeles then the capacity of the city was determined to plant an additional one million trees (McPherson et al., 2011). An accurate estimate of urban tree canopy cover is essential for urban forest management plans and policies within a city to help maintain and improve ecosystem services and quality of life (Nowak et al., 2013). Thus, even a single tree needs to be taken into account while quantifying urban forest within a city.

With technological advancement, remote sensing technology, which offers various data sources (LiDAR, high-resolution multi-band satellite images, etc.), along with different approaches, have been used to map and estimate tree canopy cover in recent years. However, these data sources and methods have some limitations, such as the availability of images only for a short time ago or the price of the data, in estimating urban tree canopy cover and monitoring its long-term change. The aerial photo-interpretation-based sampling method is the most common method used to assess the tree canopy cover and monitor its temporal changes (Nowak et al., 1996, Walton et al., 2008, Doick et al., 2020). There are many studies have been conducted using aerial photo interpretation-based sampling methods in assessing urban forest tree canopy cover (Nowak et al. 1996, Walton et al. 2008, Nowak and Greenfield 2012, Merry et al. 2014, Ucar et al. 2016, Doick et al. 2020) and landuse land cover classification change (Corona et al. 2007, Nowak and Greenfield 2010, Nowak and Greenfield 2012). It has been proved that this method is practical and economical compared to field-based sampling and remote sensing-based classification, and the results of the studies showed similarities with field measurement and remote sensing-based classification methods (Walton et al. 2008)

Several sampling approaches have been developed to estimate tree canopy cover and monitor its temporal changes accurately. Random point-based sampling is the most known and widely used sampling approach in urban tree canopy cover assessment. In this method, random points are located within the study area boundary, then are classified from aerial photo interpretation whether falling on a tree crown or not falling on a tree crown (1/0 or yes/no). For instance, Nowak and Greenfield (2012) used the random point sampling approach to assess tree cover change for 20 cities in the USA over a five-year period. Merry et al. (2014) also used the same method to assess urban tree cover change between 1951-2010 for two big cities of the USA. Likewise, Doick et al. (2020) applied a random point sampling method to assess the historical urban tree canopy cover of Great Britain. In our study, the main objective is to evaluate the definition of urban forestry in Turkey and then apply the most common methods to assess urban tree canopy cover between 1984 and 2015 for the case of Duzce city.

\section{MATERIAL AND METHODS}

\subsection{Study area}

The selected study area is located in the western Black Sea Region of Turkey and around $230 \mathrm{~km}$ east of Istanbul. Düzce city is relatively flat and surrounded by mountains. The elevation of the city ranges from $100 \mathrm{~m}$ to $1800 \mathrm{~m}$. About $50 \%$ of the city is covered with forest, which is mainly in the mountains. The flat includes Düzce Great Plain, mainly composed of alluvial soil and classified as fertile agricultural lands. Since the 19th century, Düzce city has always had a dynamic structure and faced immigration issues due to the geographical location, is located on a transit route, and being close to metropolitan areas (Istanbul, Ankara, and Bursa). In particular, rapid industrialization, terror incidents (in the 1980s) in the eastern part of the country, and natural disasters (earthquake in 1999) have accelerated urbanization in Düzce city. Hence, agricultural and forested areas have resulted in converting into settlement areas in the Düzce Great Plain. In 2017, Düzce Great Plain, which consists of the city center with a population of about 250,000 (about $63 \%$ of the total population of the city), and most settlement areas of the entire Düzce city, was declared as a conservation area in order to reduce urbanization impacts and to protect fertile agricultural lands and forested areas due to population increase (Figure 1). Since then, no other settlement has not allowed within the boundary of the Düzce Great Plain Conservation area (GPCA). Thus, the GPCA boundary was used as a study area to understand how urban tree cover change over time due to urban expansion.
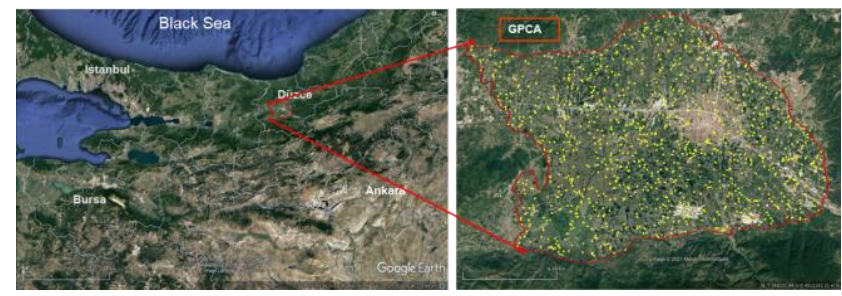

Figure 1. Study area - the boundary of Düzce Great Plain Conservation area (GPCA)

\subsection{Methods}

In this study, aerial photography from 1984, 1999, and 2015 was used to compare differences in urban tree canopy cover within GPCA, including Düzcev city center. For 2015, a digital orthophoto, acquired from the General Directorate of Mapping (HGM), was used for the analysis. It is available as a natural color image with $30 \mathrm{~cm}$ spatial resolution. Individual aerial photographs were obtained from the General Directorate of Mapping (HGM) for 1984 and 1999 with a scale of 1/16000 and $1 / 35000$, respectively. Each of the photos was georectified using the orthophotos from 1994 and 2011 as a reference. In the georectification processes, 150-200 reference points were taken for each photo to have lower RMSE, meaning a bettergeoreferenced image.

Random point sampling approach was employed for tree canopy cover estimation. 1000 random points were located within the boundary of GPCA. Minimum samples were suggested as 100 points per class by Congalton and Green (2009) for a large area, but our sample size, 1000 points, go beyond the minimum requirements. Also, our sample size is similar to recent studies that been employed random point sampling, and i-Tree, developed by U.S. Forest Service, suggesting 500-1000 random points to estimate urban canopy cover (Nowak ve Greenfield 2012, Merry vd. 2014, Ucar et al. 2016). 
In this study, the random points generator in ArcGIS was used to create the random points. After laying points on in the same geographic position on sets of aerial photographs (from 1986, 1999, and 2015), they were manually interpreted to determine whether the location of each point fell onto a tree crown (1) or did not fall onto tree crown (0). A paired image interpretation was conducted (interpreter classified each point by contrasting and classifying the image points in sequence, starting from most recent images to the oldest images) (Nowak and Greenfield 2012, Merry et al. 2014). The percent of tree canopy cover (p) was estimated by dividing the number of the sample points (x) interpreted as the presence of tree crown by the total number of sample points (n) within the GPCA boundary for each year $(p=x / n)$. Then, the standard error of the estimate (SE) was calculated from equation $(p(1-p) / n)^{0.5}$ (Lindren and McElrath 1969, Nowak ve Greenfield 2012). A 95\% confidence interval was set and calculated using the standard error (Thompson 2002). McNemar's test, a non-parametric test used on nominal data, was used to determine whether observed changes in canopy coverage are statistically significant (Sokal and Rohlf, 2003). The chi-squared value provided by the test is compared against a $\mathrm{p}$-value for statistical significance. If the $\mathrm{p}<0.05$ canopy cover between the years is considered as significantly different.

\section{RESULTS}

Based on the re-definition of urban forestry, the urban tree canopy cover of GPCA in Düzce was evaluated between 19842015 by using a random point sampling approach in this study. Tree canopy cover ranged from $16.0 \%$ to $27.4 \%$ within the study period (Table 1). We estimated that $16.2 \%$ (43.9 km2) of the land within the boundary of GPCA was covered trees in $1984,27.4 \%(74.2 \mathrm{~km} 2)$ was covered with trees in 1999 , and $16.0 \%(43.3 \mathrm{~km} 2)$ was covered with trees in 2015 . The standard errors used for the confidence interval were the same (1.2\%) for 1984 and 2015, and the resulting confidence interval was [13.718.3\%] and [13.9-18.5\%] for 1984, 2015, respectively. SE employed for the CI was $1.4 \%$ in 1999 , slightly higher than other periods. Hence, $95 \%$ of the CI was [24.6 - 30.2\%], not overlapping with CI in 1984 and 2015. Also, statistical test (McNemar's test) results showed that the changes in tree canopy cover from 1984 to 1999 and from 1999 to 2015 were statistically significant $(\mathrm{p}<0.05)$. However, when compared 1984 to 2015 , tree canopy cover changes were significantly different $(\mathrm{p}>0.05)$.

\begin{tabular}{lllll}
\hline & $\begin{array}{l}\text { Estimated } \\
\text { Canopy } \\
\text { Cover }(\%)\end{array}$ & $\begin{array}{l}\text { Area } \\
\left(\mathrm{km}^{2}\right)\end{array}$ & $\begin{array}{l}\text { Standard } \\
\text { Error } \\
(\%)\end{array}$ & $\begin{array}{l}\text { \%95 } \\
\text { Confidence } \\
\text { Interval }(\%)\end{array}$ \\
\hline 1984 & 16.2 & 43.9 & 1.2 & $13.7-18.3$ \\
1999 & 27.4 & 74.2 & 1.4 & $24.6-30.2$ \\
2015 & 16.0 & 43.3 & 1.2 & $13.9-18.5$ \\
\hline
\end{tabular}

Table 1. Summary statistic of assessed urban tree canopy cover with the random point sampling approach within GPCA

Also, the transitions in tree canopy cover between periods were examined within GPCA by following cases (Merry et al., 2014):

\footnotetext{
1. Tree canopy in 1984 -Tree canopy in 1999

2. Tree canopy in 1984 -Tree canopy in 2015

3. Tree canopy in 1999 -Tree canopy in 2015
}

\author{
4. Tree canopy in 1984 - Not tree canopy in 1999 \\ 5. Tree canopy in 1984 - Not tree canopy in 2015 \\ 6. Tree canopy in 1999 -Not tree canopy in 2015 \\ 7. Not tree canopy in 1984 - Tree canopy in 1999 \\ 8. Not tree canopy in 1984 - Tree canopy in 2015 \\ 9. Not tree canopy in 1999 - Tree canopy in 2015

10. Not tree canopy in 1984 - Not tree canopy in 1999
11. Not tree canopy in 1984 - Not tree canopy in 2015
12. Not tree canopy in 1999 - Not tree canopy in 2015

In the examination of transition between 1984 and 1999, only about $10.9 \%$ of the sampled land area was covered with trees during both periods (Table 2). 5.3\% of sample land was covered trees in 1984 but was not covered in 1999. About $16.5 \%$ of sampled land was not covered with trees in 1984 yet was covered in 1999. When examining the transition from 1999 to 2015 , about $11.2 \%$ of the sampled land area was covered for both periods. However, about $16.2 \%$ of tree canopy cover in 1999 was not tree canopy in 2015 . Only about $4.8 \%$ of sampled land was not covered by the tree in 1999 yet was covered in 2015. In the transition of tree cover between 1984 and 2015, For both periods, only about $6.4 \%$ of sampled land was covered with trees. About $9.8 \%$ of sampled land was covered with trees in 1984 but was not covered in $2015.9 .6 \%$ of sampled land was not covered with trees in 1984, while it was covered in 2015.

\begin{tabular}{|c|c|c|c|}
\hline \multirow[b]{2}{*}{1984} & \multicolumn{3}{|c|}{1999} \\
\hline & $\begin{array}{l}\text { Tree } \\
(\%)\end{array}$ & Not tree $(\%)$ & Total $(\%)$ \\
\hline Tree $(\%)$ & 10.9 & 5.3 & 16.2 \\
\hline Not tree $(\%)$ & 16.5 & 67.3 & 83.8 \\
\hline \multirow[t]{2}{*}{ Total (\%) } & 27.4 & 72.6 & 100 \\
\hline & \multicolumn{3}{|c|}{2015} \\
\hline 1984 & $\begin{array}{l}\text { Tree } \\
(\%)\end{array}$ & Not tree $(\%)$ & Total $(\%)$ \\
\hline Tree $(\%)$ & 6.4 & 9.8 & 16.2 \\
\hline Not tree $(\%)$ & 9.6 & 74.2 & 83.8 \\
\hline \multirow[t]{2}{*}{ Total $(\%)$} & 16.0 & 84.0 & 100 \\
\hline & \multicolumn{3}{|c|}{2015} \\
\hline 1999 & $\begin{array}{l}\text { Tree } \\
(\%)\end{array}$ & Not tree $(\%)$ & Total $(\%)$ \\
\hline Tree $(\%)$ & 11.2 & 16.2 & 27.4 \\
\hline Not tree $(\%)$ & 4.8 & 67.8 & 72.6 \\
\hline Total (\%) & 16.0 & 84.0 & 100 \\
\hline
\end{tabular}

Table 2. Urban tree canopy cover transitions between years.

\section{DISCUSSION AND CONCLUSION}

In this study, our finding showed that the overall estimated urban tree canopy cover in GPCA, Düzce changed between 1984 and 2015. Urban tree canopy cover increased from 16.2\% in 1984 to $27.4 \%$ in 1999 while tree canopy covered decreased to $16.0 \%$ in 2015 . A recent study conducted by Nowak and Greenfield (2020) showed that the average global urban tree canopy cover was $26.5 \%$, but this rate can be changed among biomes regions (forest, grassland, desert, rock/Ice/Tundra) and 
countries. Our study area is mainly used for agricultural purposes. The findings for tree canopy cover of agricultural land cover in forest and grassland regimes are comparable to recent estimates of Nowak and Greenfield (2020). Also, differences in urban canopy cover between 1984-1999 and 1999-2015 were statistically significant. However, there was no statistical difference in comparing the changes in tree canopy cover from the beginning of the study period to the end of the study period.

Both total urban tree canopy cover and its geographic distribution over the study period have changed. In particular, the transition from tree cover to no tree cover, from not tree cover to tree cover or remaining in same conditions within each period, showed quite differences. The reasons for the distribution and extent of urban canopy cover change in the study area are mainly related to the introduction of poplar tree plantation and urban development. Poplar, a fast-growing species, was introduced to Turkey in 1962 as a result of an agreement between the Turkish Government and FAO to meet wood production demands (Velioğlu and Akgül 2012). Although poplar tree plantation is considered an urban forest, compared to hazelnut farm (in a shrub from), FAO suggested that if 5\% of the total agricultural land is used for poplar plantation, there will be no harm to agricultural land (Atilgan, 1997). In visual comparison, it can be clearly seen that mostly agricultural lands are converted into poplar tree plantations (Figure 2). Thus, an increase in canopy cover was observed in 1999. Hence, in addition to two cover classes (tree-not tree), more land cover classes such as impervious surface, grassland, poplar plantation, or hazelnut farm can be used to clearly address the transition of canopy cover and urbanization over the years.

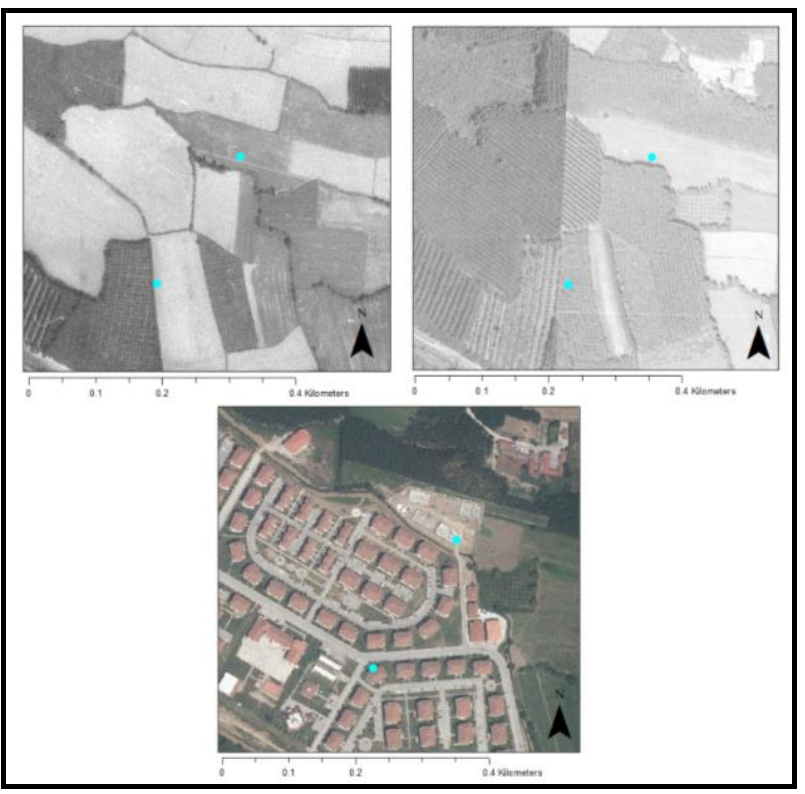

Figure 2. Example of canopy cover transition for the periods (1984 -upper left, 1999 -upper right, and 2015 -bottom)

In some respect, the use of aerial photographs with a random sampling approach for urban tree canopy cover assessment offers a relatively accurate, cost and time-effective alternative compared to the traditional ground sampling approach. However, it may be challenging to interpret urban trees on vertical imagery due to spectral separability between trees and near features, shadows of the crown, and other objects. In addition, the factors, including combined effects of misregistration, topographic displacement, minor georeferencing problems, parallax, and other image processing problems, could bring bias or error into our findings (Merry et al., 2014, Ucar et al., 2016). Given a large enough sample size (1000 sample points providing a SE less than the suggested maximum standard error of $1.6 \%$ ) could reduce the effect of these factors and the error.

Urban trees provide many benefits to society, but the amount of urban tree cover in cities may vary globally based on the definition of the urban forest. For this study, regarding the traditional definition of the urban forest in Turkey, even a single tree within a city boundary is considered for the definition of urban forestry. Urban tree canopy cover was assessed using a random sampling point approach within the boundary of GPCA, which is heavily populated. The changes in canopy cover were estimated from 1984 to 2015 . The result of the study showed that the urban canopy cover was increased from $16.2 \%$ in 1980 to $27.4 \%$ in 1999 (the change was statistically significant) while it was decreased between 1999 and 2015 (the change was statistically significant). Although the estimated urban tree canopy cover in 1984 was relatively similar to the estimated urban tree canopy cover in 2015 (the changes not statistically significant), the transition from tree canopy to not canopy classes can be observed. As the human population increase, urban development will put on pressure on natural resources. In particular, forest and agricultural areas will convert into urban areas, and their associated benefits will not be maintained. Thus, an accurate estimate of urban tree canopy cover and monitoring long-term canopy cover changes are essential to determine the current situation and the trends for the future. It will be helpful for urban forest management plans and policies within a city to help maintain and improve ecosystem services and quality of life. Photo-interpretation of aerial images with the random sampling approach is simple, time and cost-effective to assess urban tree cover and monitor the changes.

\section{REFERENCES}

Akbari, H. 2002. Shade trees reduce building energy use and $\mathrm{CO} 2$ emissions from power plants. Environmental Pollution, 116, S119-S126.

Atılgan, V. 1997. Türkiye kavakçılığının sorunları ve çözüm Yolları. Y.Lisan tezi. İstanbul Üniversitesi Fen Bilimleri Enstitüsü.

Berland, A. 2012. Long-term urbanization effects on tree canopy cover along an urban-rural gradient. Urban Ecosystems, 15(3), 721-738.

Congalton,R.G., and Green, 2009. AssessingtheAccuracyofRemotelySensedData, Principles and Practices,secondedition.CRCPress,BocaRaton,FL.

Congalton, R.G., \& Green, K. 2019. Assessing the Accuracy of Remotely Sensed Data: Principles and Practices, Second edition. CRC Press. Boca Raton, FL.

Corona, P., Fattorini, L., Chirici, G., Valentini, R., \& Marchetti, M. 2007. Estimating forest area at the year 1990 by two-phase sampling on historical remotely sensed imagery in Italy. Journal of Forest Research, 12(1), 8-13.

Dwyer, J. F., Schroeder, H. W., \& Gobster, P. H. 1991. The significance of urban trees and forests: toward a deeper 
understanding of values. Journal of Arboriculture 17 (10): 276$284,17(10)$.

Doick, K. J., Buckland, A., \& Clarke, T. K. 2020. Historic Urban Tree Canopy Cover of Great Britain. Forests, 11(10), 1049 .

Food and Agriculture Organization of the United nations (FAO) . 2017. "Urban and Peri-urban Forestry". Retrieved from http://www.fao.org/forestry/urbanforestry/87025/en/. Son erişim 5 Mart 2021

Grove, J. M., O'Neil-Dunne, J., Pelletier, K., Nowak, D., \& Walton, J. 2006. A report on New York City's present and possible urban tree canopy, United States Department of Agriculture, Forest Service, Northeastern Area, South Burlington, Vermont.

Jorgensen, E. 1974. Towards an urban forestry concept. Proceedings of the 10th Commonwealth Forestry Conference. Ottawa, Canada; Forestry Service.

Kaspar, J., Kendal, D., Sore, R., \& Livesley, S. J. 2017. "Random point sampling to detect gain and loss in tree canopy cover in response to urban densification", Urban Forestry \& Urban Greening, 24, 26-34.

Konijnendijk, C. C., \& Randrup, T. B. 2004. page 471-478. Urban forestry. Encyclopedia of Forest Sciences (Eds. Burley, J., Evans, J. and Younquist, JA). Elsevier Science, London.

Konijnendijk, C. C., Ricard, R. M., Kenney, A., \& Randrup, T. B. 2006. Defining urban forestry-A comparative perspective of North America and Europe. Urban Forestry \& Urban Greening, 4(3-4), 93-103.

Lindgren, B. W. 1966. Introduction to probability and statistics/by BW Lindgren, and GW McElrath (No. 519.5 L55.).

McPherson, E. G., Simpson, J. R., Xiao, Q., \& Wu, C. 2011. Million trees Los Angeles canopy cover and benefit assessment. Landscape and Urban Planning, 99(1), 40-50.

Merry, K., Siry, J., Bettinger, P., \& Bowker, J. M. 2014. Urban tree cover change in Detroit and Atlanta, USA, 1951-2010. Cities, 41, 123-131.

Mesire Yerleri Yönetmeliği (MYY), 2006. Çevre ve Orman Bakanlığı, Resmi Gazete Tarihi: 30/10/2006 - Resmi Gazete Say1s1 : 26305

Miller, R. W., Hauer, R. J., \& Werner, L. P. 2015. Urban forestry: planning and managing urban greenspaces. Third edition. Long Grove, IL, Waveland Press, Inc.

Nowak, D. J., Rowntree, R. A., McPherson, E. G., Sisinni, S. M., Kerkmann, E. R., \& Stevens, J. C. 1996. Measuring and analyzing urban tree cover. Landscape and Urban Planning, 36(1), 49-57.

Nowak, D. J., Crane, D. E., \& Stevens, J. C. 2006. Air pollution removal by urban trees and shrubs in the United States. Urban Forestry \& Urban Greening, 4(3-4), 115-123.

Nowak, D. J., \& Greenfield, E. J. 2010. Evaluating the National Land Cover Database tree canopy and impervious cover estimates across the conterminous United States: a comparison with photo-interpreted estimates. Environmental management. 46(3), 378-390.

Nowak, D. J., \& Greenfield, E. J. 2012. Tree and impervious cover change in US cities. Urban Forestry \& Urban Greening, 11(1), 21-30.

Nowak, D. J., Greenfield, E. J., Hoehn, R. E., \& Lapoint, E. 2013. Carbon storage and sequestration by trees in urban and community areas of the United States. Environmental pollution, $178,229-236$.

Nowak, D. J., \& Greenfield, E. J. 2020. The increase of impervious cover and decrease of tree cover within urban areas globally (2012-2017). Urban Forestry \& Urban Greening, 49, 126638

Parmehr, E. G., Amati, M., Taylor, E. J., \& Livesley, S. J. 2016. Estimation of urban tree canopy cover using random point sampling and remote sensing methods. Urban Forestry \& Urban Greening, 20, 160-171.

Pasher, J., McGovern, M., Khoury, M., \& Duffe, J. 2014. "Assessing carbon storage and sequestration by Canada's urban forests using high resolution earth observation data. Urban Forestry \& Urban Greening, 13(3), 484-494.

Randrup, T. B., Konijnendijk, C., Dobbertin, M. K., \& Prüller, R. 2005. The concept of urban forestry in Europe. In Urban forests and trees (pp. 9-21). Springer, Berlin, Heidelberg.

Richardson, J. J., \& Moskal, L. M. 2014. Uncertainty in urban forest canopy assessment: Lessons from Seattle, WA, USA. Urban Forestry \& Urban Greening, 13(1), 152-157.

Safford, H., Larry, E., McPherson, E.G., Nowak, D.J., Westphal, L.M. (August 2013). Urban Forests and Climate Change. US Department of Agriculture, Forest Service, Climate Change Resource Center. www.fs.usda.gov/ccrc/topics/urban-forests

Sağlam, S. \& Özkan, U.Y. 2011. "Kent Orman Kavramı ve Planlama Örnekleri", I. Ulusal Akdeniz Orman ve Çevre Sempozyumu 555-568, 26-28 Ekim 2011, Kahramanmaraş.

Sağlam, S., \& Elvan, O. D. 2017. Kent ormanlarının Türkiye'deki gelişimi ve hukuki durumu. Kastamonu Univ. Orman Fakültesi Dergisi, 17(4), 669-681.

Sokol, R.R. and F.J. Rohlf. 2003. Biometry: The Principles and Practices of Statistics in Biological Research. WH Freeman and Company, New York, NY.

Ucar, Z., Bettinger, P., Merry, K., Siry, J., Bowker, J. M., \& Akbulut, R. 2016. A comparison of two sampling approaches for assessing the urban forest canopy cover from aerial photography. Urban Forestry \& Urban Greening, 16, 221-230.

United Nation, The World Urbanization Prospects (2018). Retrieved from
f https://www.un.org/en/events/citiesday/assets/pdf/the_worlds_ci ties_in_2018_data_booklet.pdf

Velioğlu, Ercan, and Selda Akgül. "Poplars and willows in Turkey: country progress report of the National Poplar Commission." Time period 2015 (2012). 
Walton, J. T., Nowak, D. J., \& Greenfield, E. J. 2008. Assessing urban forest canopy cover using airborne or satellite imagery. Arboriculture \& Urban Forestry. 34(6):334-340

Wold Bank. (2017). (Dünya Bankası Göstergeleri), https://data.worldbank.org/indicator/SP.URB.TOTL.IN.ZS?cont extual=default.

Yeşil, A., Zengin, H., Özkan, U. Y., \& Sağlam, S. 2010. GIS, GPS and Remote Sensing Applications in Forest Management Planning of the Urban Forests of Istanbul Municipality. International Journal of Arts and Sciences, 3(9), 227-239. 